\title{
Sundial Horizontal dalam Penentuan Penanggalan Jawa Pranata Mangsa
}

\author{
Muhammad Himmatur Riza* \\ Universitas Islam Negeri (UIN) Walisongo Semarang \\ Email: muhammadhimmaturriza@gmail.com
}

\begin{abstract}
Sundial as a historic astronomical instrument that can be used in solving several basic astronomical problems. The "Pranata Mangsa" Javanese calendar which the determination is based on the position of the sun becomes a reliable thing to be calculated. There has been an existing method that some farmers use their feet soles to determine the first "mangsa" in "pranata mangsa" Javanese calendar. According to the author, this method doesn't produce an accurate result. Regarding to the ineffective "pranata mangsa" javanese calendar determination, sundial can be used to solve the problems of "pranata mangsa" Javanese calendar determination. A qualitative research is used in this paper with descriptive-analytic approach which aims to know the in-depth description that illustrate the concept of astronomy of the "horizontal sundial" and analyze the mathematical concept of the position of the sun and others data that are required in the determination of the "pranata mangsa" Javanese calendar. This research uses data collecting techniques through field research which is considering the horizontal sundial as a primary data and the participant observation for the observation method and experiment for finding some important data. The secondary data of the research comes from some literatures and documents in a form of books, articles and papers which is related to the research object. The finding of this research is the determination of the "pranata mangsa" javanese calendar using "horizontal sundial" method uses feet soles of a person which is reliable to get an accurate result. This is purely coming from the way how some Javanese people determine the "pranata mangsa" Javanese calendar directly in field.
\end{abstract}

Keywords: Calendar, Java, Sundial, Sun

* Mahasiswa Pascasarjana Ilmu Falak Universitas Islam Negeri (UIN) Walisongo, Semarang. 
$120 \mid$ Muhammad Himmatur Riza

\begin{abstract}
Abstrak
Sundial sebagai instrumen astronomi bersejarah yang dapat digunakan dalam menyelesaikan masalah-masalah dasar astronomi. Penanggalan Jawa Pranata Mangsa yang penentuannya berdasarkan posisi Matahari menjadi hal yang dapat diperhitungkan. Metode yang sudah ada yaitu para petani menggunakan pecak kaki untuk mengetahui kapan masuk awal mangsa dalam penanggalan Jawa Pranata Mangsa Metode tersebut menurut penulis tidak menghasilkan hasil yang akurat. Melihat cara penentuannya yang seperti itu, Sundial dapat mengatasi problem tersebut untuk digunakan sebagai salah satu metode dalam penentuan Penanggalan Jawa Pranata Mangsa. Dalam tulisan ini digunakan penelitian yang bersifat kualitatif dengan pendekatan deskriptif-analitik yang bertujuan untuk mengetahui uraian secara mendalam yang menggambarkan konsep astronomis yang terdapat dalam Sundial Horizontal dan menganalisa konsep matematisnya mengenai posisi Matahari dan data lainnya yang diperlukan dalam penentuan Penanggalan Jawa Pranata Mangsa. Dengan teknik pengumpulan data melalui penelitian lapangan (field research) yaitu menggunakan Sundial Horizontal sebagai data primer dengan metode observasi partisipan dan eksperimen. Sedangkan data sekunder berasal dari literatur dan dokumen berupa buku, tulisan, makalah-makalah yang berkaitan dengan obyek penelitian. Hasil temuan dalam penelitian ini Penentuan penanggalan Jawa Pranata Mangsa menggunakan Sundial Horizontal (Sundial Pranata Mangsa) lebih akurat dibandingkan dengan menggunakan pecak kaki seseorang, ini murni dari bagaimana pengguna melaksanakan praktek lapangan secara langsung dalam penentuan penanggalan Jawa Pranata Mangsa.
\end{abstract}

Kata Kunci: Kalender, Jawa, Sundial, Matahari

\title{
Pendahuluan
}

Telah kita ketahui, bahwa petani Jawa sangat akrab dengan iklim yang telah mendarah daging dalam kehidupan. ${ }^{1}$ Oleh karena itu tak heran jika masyarakat Jawa memiliki ilmu membaca tanda-tanda alam untuk menentukan perhitungan musim yang akan digunakan dalam

1 Sindhunata, Seri Lawasan Pranata Mangsa, (Jakarta: Kepustakaan Populer Gramedia, 2011), 2.

Ulul Albab: Jurnal Studi dan Penelitian Hukum Islam 

mengelola lahan płrtanian yang disebut dengan Pranata
Mangsa. $^{2}$

Pranata Mangsa merupakan warisan leluhur yang disusun dengan dasar titen (observasi) selama bertahun-tahun lamanya dan baru dibakukan oleh Sri Sunan Paku Buwana VII di Surakarta padatanggal 22 Juni $1855 .{ }^{3}$ Pembakuan tersebut untuk menguatkan sistem penanggalan yang mengatur tata kerja kaum petani. Penanggalan musim ini mengikuti peredaran matahati dari tahun ke tahun yang panjangnya 365 hari. ${ }^{4}$

Penanggalan Jawa Pranata Mangsa merupakan salah satu warisan peradaban manusia yang sangat masyhur dan penting bagi kelangsungan hidup manusia khususnya masyarakat Jawa. Tanpa adanya kalender atau penanggalan akan terasa hambar, karena masyarakat akan kesulitan dalam menentukan program kegiatan yang akan mereka lakukan, terutama program yang berkaitan dengan waktu. Dan dengan adanya kalender atau penanggalan memudahkan manusia untuk mengidentifikasi dan menandai peristiwa atau kejadian yang telah berlalu. Di dunia ini banyak macam sistem kalender atau penanggalan yang berkembang. Menurut sebuah studi tahun 1987, ada sekitar 40 sistem kalender yang saat ini berkembang di dunia dan dikenal dalam pergaulan internasional, namun secara umum dikategorikan ke dalam tiga mazhab besar dalam perhitungan kalender $^{5}$ seperti Solar Calendar (Kalender

2 Rini Fidiyani dan Ubaidillah Kamal, Cara berhukum Orang Banyumas dalam Pengelolaan Lahan Pertanian (Studi Berdasarkan Antropologi Hukum), (Semarang: Fakultas Hukum Universitas Negeri Semarang. PDF), 702.

${ }^{3}$ Sukardi Wisnubroto, Pengenalan waktu Tradisional Pranata Mangsa dan Wariga menurut Jabaran Meteorologi Manfaatnya dalam Pertanian dan Sosial, (Yogyakarta: Mitra Gama Widya, 1999), 16.

${ }^{4}$ N. Daljoeni, Penanggalan Pertanian Jawa Pranata Mangsa, (Yogyakarta: Proyek Javanologi, 1983), 4.

${ }^{5}$ Tono Saksono, Mengkompromikan Rukyat E Hisab, (Jakarta : Amythas Publicita, 2007), 47. 
$122 \mid$ Muhammad Himmatur Riza

Matahari), Lunar Calendar (Kalender bulan), dan Lunisolar Calendar (Kalender bulan Matahari) ${ }^{6}$.

Muhyiddin Khazin dalam bukunya "Ilmu Falak Dalam Teori dan Praktik" menyebutkan bahwa terdapat tiga macam penanggalan yang telah mendarah daging dan mengakar kuat dengan pola kehidupan masyarakat di Indonesia, khususnya masyarakat Jawa, yaitu penanggalan $\mathrm{Masehi}^{7}$, penanggalan Hijriyah ${ }^{8}$, dan penanggalan Jawa Islam. ${ }^{9}$

${ }^{6}$ Dalam kalender ini, satu tahun lamanya 365.2422 hari (sama seperti kalender matahari) namun pergantian bulan disesuaikan dengan periode fase bulan ( 1 bulan $=29.5306$ hari). Normalnya kalender ini terdiri dari 12 bulan.Satu bulan ada yang lamanya 29 hari dan 30 hari. Jika dihitung, dalam setahun hanya ada $12 \times 29.5309$ hari $=354$ hari. Lebih cepat 11 hari dari yang seharusnya.Agar kalender ini tetap konsisten dengan pergerakan matahari, dibuatlah tahun kabisat yang terdiri dari 13 bulan sebanyak 7 kali dalam 19 tahun.Kelebihan kalender ini adalah konsistensinya dengan musim sekaligus penggunaannya untuk keperluanibadah. Contoh kalender matahari-bulan adalah kalender Cina (imlek), kalender Arab pra-Islam dan kalender Yahudi. Lihat dalam Ruswa Darsono, Penanggalan Islam (Tinjauan Sistem, Fiqih dan Hisab Penanggalan), (Yogyakarta:Labda Press, 2010), 33.

7 Kalender ini menggunakan pergerakan Matahari sebagai dasar perhitungan, patokan utamanya adaah ketika Matahari berkedudukan di equator atau ketika lama siang dan malam hari sama panjangnya pada awal musim semi di belahan bumi bagian utara. Satu tahun adalah lama Matahari beredar dari titik musim semi ke titik musim semi berikutnya, terdiri dari 365 hari 5 jam 48 menit 46 detik (365.2422) atau lamanya waktu rata-rata yang diperlukan Bumi untuk mengelilingi Matahari. Kalender Masehi (Gregorian) yang kita gunakan sehari-hari adalah contoh kalender Matahari (Solar Calendar). Kelebihan kalender ini adalah kesesuainnya dengan musim, karena dasar perhitungan pada awalnya juga pergeseran musim. Lihat dalam Ruswa Darsono, Ibid., 32.

${ }^{8}$ Sistem penanggalan ini memanfaatkan perubahan fase Bulan sebagai dasar perhitungan waktu. Dalam perjalanannya mengelilingi Bumi, fase Bulan akan berubah dari Bulan mati ke Bulan sabit, Bulan separuh, Bulan lebih separuh, purnama, Bulan separuh, Bulan sabit, dan kembali ke Bulan mati. Satu periode dari Bulan mati ke Bulan mati lamanya rata-rata 29 hari 12 jam 44 menit 3 detik (29.5306 hari), periode ini disebut dengan periode sinodis Bulan. Panjang tahun dalam penanggalan hijriyah adalah 12 bulan $(12 \mathrm{x}$

Ulul Albab: Jurnal Studi dan Penelitian Hukum Islam 
Prinsip penanggalan Jawa Pranata Mangsa yang berbasis peredaran Matahari di langit ini digunakan sebagai bagian dari keselarasan hidup mengikuti perubahan irama alam dalam satu tahun. Prinsip awal penanggalan Jawa Pranata Mangsa mengenal mangsa Kasa (pertama) yang terjadi pada tanggal 22 Juni, yaitu saat posisi Matahari berada pada garis balik utara, sehingga para petani mampu mengetahui bayangan terpanjang (empat pecak ${ }^{10}$ kaki ke arah selatan). Mangsa Kasa (pertama) ini berakhir di saat bayangan menjadi tiga pecak. Prinsip selanjutnya dalam penanggalan Jawa Pranata Mangsa mengenal mangsa Karo (kedua) sampai mangsa Kapat (keempat) yang berakhir ketika bayangan tepat berada di kaki saat posisi Matahari berada di zenit. Pergerakan garis edar Matahari ke selatan mengakibatkan pemanjangan bayangan ke utara dan mencapai maksimum sepanjang dua pecak kaki di saat posisi Matahari berada pada garis balik selatan (22 Desember) dan menandai berakhirnya mangsa Kanem (keenam). Selanjutnya proses berulang secara simetris untuk mangsa Kapitu (ketuju) hinga mangsa Sadha (kedua belas). ${ }^{11}$ Kalau dilihat dari cara penentuannya konsep penanggalan Jawa Pranata Mangsa yang seperti itu menghasilkan hasil yang kurang akurat, karena ukuran tinggi badan dan pecak kaki itu sangat relatif dan setiap orang mempunyai ukuran tinggi badan serta panjang pecak kaki yang berbeda-beda.

Melihat cara penentuannya yang seperti itu, akhir-akhir ini alat astronomi klasik yakni Sundial atau jam Matahari mulai

29.5306 hari), yakni 354 hari 8 jam 48 menit 34 detik (354.3672 hari).Lihat dalam Ruswa Darsono, Ibid., 32-33.

${ }_{9}$ Muhyiddin Khazin, Ilmu Falak dalam Teori dan Praktik, (Yogyakarta: Buana Pustaka), 103.

${ }^{10}$ Bidang kaki sebelah bawah, biasa digunakan untuk menapak.

${ }^{11}$ Dafidslametsetiana.blogspot.com/2015/11/etnomatematikapranatamangsa.html?m=1. Diakses pada tanggal 5 Desember 2016 pukul 22:57 WIB. 
$124 \mid$ Muhammad Himmatur Riza

dikembangkan kembali oleh para astronom-astronom modern, dari segi bahan dan bagian-bagian serta fungsinya pun semakin variatif. Salah satunya untuk penentuan penanggalan Jawa Pranata Mangsa.

\section{Pengertian Sundial}

Sundial atau jam Mataharia dalah suatu alat yang menunjukkan waktu berdasarkan posisi Matahari. Cara kerja Sundial ini cukup simpel yaitu dengan memanfaatkan gerak semu Matahari yang menyebabkan posisi Matahari terhadap pengamat di Bumi bergerak secara semu sepanjang hari. Akibat pergerakan semu Matahari inilah yang kemudian menyebabkan bayangan Matahari terus bergerak, baik bentuk yang terus berubah maupun posisi dari bayangan itu sendiri seiring gerak semu Matahari sepanjang hari.12 Meskipun sederhana tetapi alat klasik Sundial ini sangat "berisi". Dan menurut catatan sejarah, Sundial merupakan jam tertua dalam peradaban manusia. ${ }^{13}$

Secara garis besar, Sundial dapat dikategorikan menjadi tiga bentuk yang mana masing-masing mempunyai tipe dan karakter yang berbeda-beda namun masih saling berkaitan, yaitu tipe Equatorial, Horizontal, dan Vertikal. ${ }^{14}$

1. Sundial Equatorial yaitu sundial yang bidangnya sesuai dengan bidang equator Bumi sehingga penempatannya harus miring sesuai dengan sudut kemiringan Bumi. ${ }^{15}$

12 http://www.cybersoe.com/index.php/soe-pedia/fisika?start=10. Diakses pada tanggal 23 Juni 2018 pukul 20:05 WIB.

${ }_{13}$ Diungkapkan oleh David A King dalam karyanya bertajuk The Astronomy of the Mamluks. Lihat di http://artrevolution.wordpress.com/category/sejarah-jam/. Diakses pada tanggal 23 Juni 2018 pukul 20:35 WIB.

14 Rene. R. J. Rohr, Sundial, History, Theory and Pactice, (New York: Dover Publications, INC, 1996), 47.

${ }^{15}$ http://anizaida89.blogspot.com/2011/09/sundials.html. Diakses pada tanggal 23 Juni 2018 pukul 21:11 WIB.

Ulul Albab: Jurnal Studi dan Penelitian Hukum Islam 
2. Sundial Horizontal atau yang biasa dikenal dengan garden sundials, karena peletakannya cukup di atas tanah. Sundial ini menerima bayangan sejajar dengan horizontal dan tidak tegak lurus dengan katulistiwa. ${ }^{16}$

3. Sundial Vertikal yaitu sundial yang diletakkan di dinding atau sesuatu yang bisa digunakan untuk menggantungkan sundial tersebut. ${ }^{17}$

Dari tiga macam tipe Sundial tersebut, menurut penulis Sundial Horizontal lah yang dapat dikaitkan dengan konsep dari penanggalan jawa Pranata Mangsa yang dapat dimanfaatkan sebagai pedoman kegiatan usaha tani, karena penanggalan jawa Pranata Mangsa ini juga berbasis pada peredaran Matahari.

\section{Metode dan Aplikasi Penentuan Penanggalan Jawa Pranata Mangsa menggunakan Sundial Horizontal.}

Instrumen yang digunakan dalam penentuan penanggalan Jawa Pranata Mangsa ini menggunakan instrumen klasik dan dapat terbilang kuno yaitu Sundial Horizontal, akan tetapi penulis mengembangkan metodemetode yang sudah ada sehingga Sundial Horizontal ini dapat digunakan untuk menentukan penanggalan Jawa Pranata Mangsa dan penulis memberi nama instrumen ini dengan nama Sundial Pranata Mangsa. Berikut gambar dari Sundial Pranata Mangsa tersebut:

${ }^{16}$ Ibid.

${ }^{17} \mathrm{Ibid}$. 
126 Muhammad Himmatur Riza

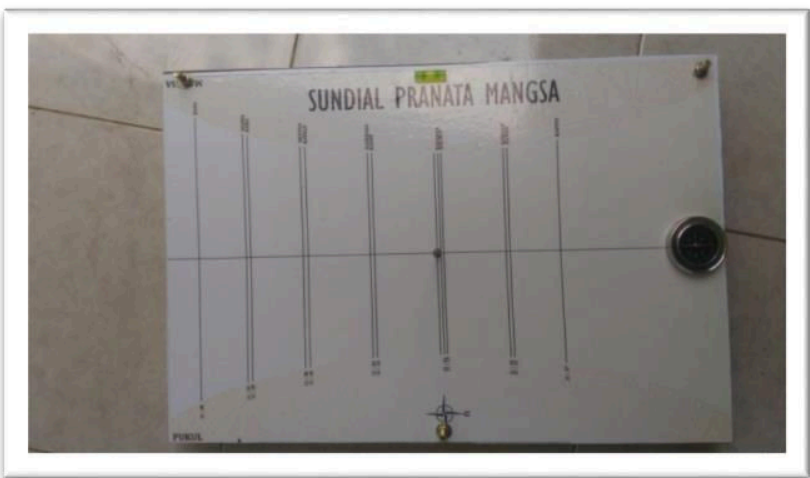

Gambar 1: Sundial Pranata Mangsa. (Sumber: Penulis)

Sundial Pranata Mangsa tersebut penulis desain dengan sangat sederhana yang mempunyai komponen sebagai berikut:

1. Gnomon atau tongkat.

Bentuk dari gnomon Sundial Pranata Mangsa ini berbentuk tegak lurus dengan bidang dial seperti sundial pada umumnya, memiliki tinggi $45 \mathrm{~cm}$. gnomon ini terbuat dari batangan besi yang ujungnya berbentuk lancip sehingga bayangan yang akan dihasilkan nanti dapat terfokus pada skala atau garis-garis yang terdapat di bidang dial. Alasan penulis memilih gnomon yang terbuat dari besi tentunya agar tidak mudah patah ketika dibawa.

Menurut penulis, tinggi gnomon $45 \mathrm{~cm}$ ini tidak terlalu panjang dan tidak terlalu pendek, karena ketika gnomon itu terlalu pendek, maka skala atau garis-garis bayangan yang dihasilkan dari gnomon nantinya terlalu dekat dan akan menyulitkan ketika pengamatan. Sedangkan pemasangan gnomon tepat berada di tengah-tengah bidang dial ini bersfungsi sebagai penunjuk awal masuk mangsa dalam penanggalan Jawa Pranata Mangsa.

Ulul Albab: Jurnal Studi dan Penelitian Hukum Islam 


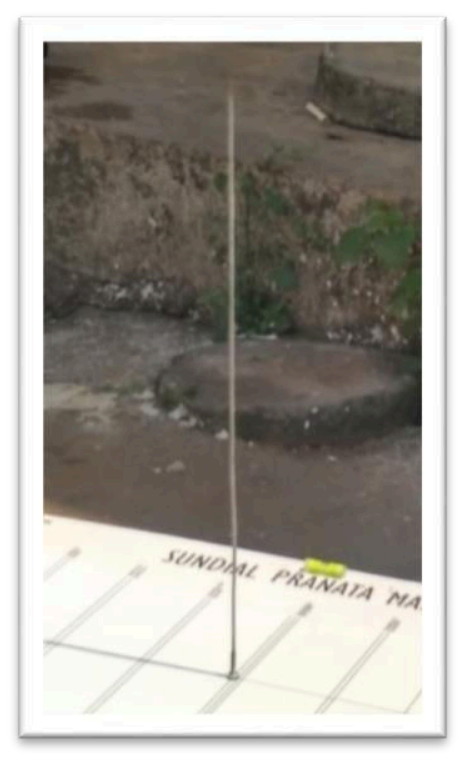

Gambar 2: Gnomon Sundial Pranata Mangsa. (Sumber Penulis)

\section{Kompas}

Kompas adalah alat yang digunakan untuk mengetahui arah. Di dalamnya terdapat jarum yang bermagnit yang senantiasa menunjukkan arah Utara dan Selatan. Hanya saja arah utara yang ditunjukkan olehnya bukanlah utara sejati (titik kutub utara). ${ }^{18}$ Meskipun yang ditunnjukkan bukan utara sejati, namun menurut penulis kompas ini sudah cukup untuk menunjukkan arah utara, sehingga penulis menggunakan kompas untuk pelengkap dalam Sundial Pranata Mangsa yang berfungsi untuk penunjuk arah.

Kompas ini terletak di sisi pinggir bidang dial dan ditempatkan di atas garis panjang yang memotong bidang dial tersebut. Fungsinya untuk mempermudah penataan sundial menghadap ke arah utara.

${ }_{18}$ Muhyiddin Khazin, Kamus Ilmu Falak, (Jogjakarta: Buana Pustaka, 2005), 31. 
$128 \mid$ Muhammad Himmatur Riza

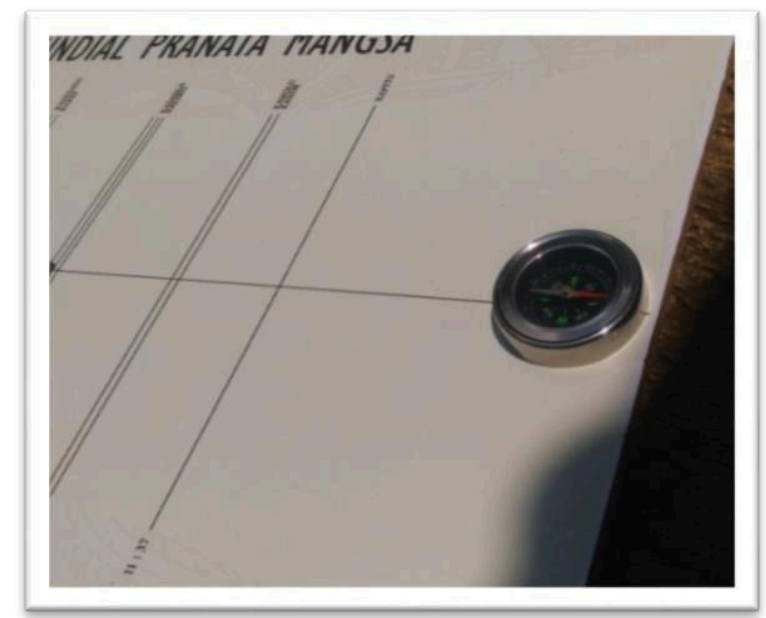

Gambar 3: Penempatan Kompas. (Sumber: Penulis)

\section{Waterpass}

Waterpass merupakan alat yang digunakan untuk mengukur atau menentukan sebuah benda atau garis dalam posisi rata baik pengukuran secara vertikal maupun secara horizontal. ${ }^{19}$ Ada banyak jenis waterpass, namun penulis menggunakan waterpass yang berbentuk tabung, karena waterpass tabung memiliki fungsi untuk mengukur kerataan secara horizontal. Dengan demikian penulis meletakkan waterpass tabung di atas bidang dial Sundial Pranata Mangsa, sehingga dengan adanya waterpass tersebut Sundial Pranata Mangsa ini benar-benar terpasang dalam keadaan rata.

19 http://id.m.wikipedia.org/wiki/waterpass. diakses pada hari Rabu, 24 Juni 2018 pukul 19.16 WIB

Ulul Albab: Jurnal Studi dan Penelitian Hukum Islam 


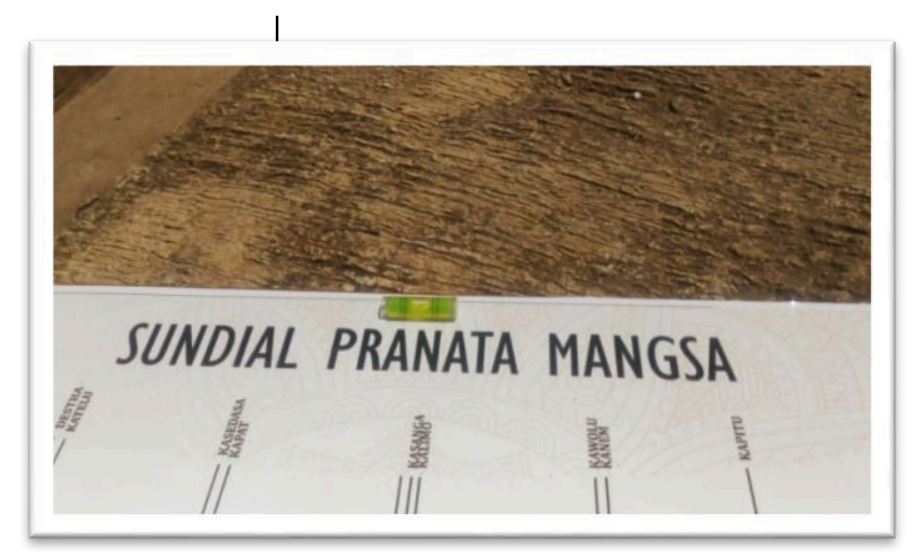

Gambar 4: Waterpass Tabung. (Sumber: Penulis)

\section{Tripod}

Tripod merupakan tempat dudukan atau penyangga alat yang fungsinya untuk menstabilkan alat. Adapaun Sundial Pranata Mangsa ini mempunyai tiga kaki atau tripod yang terbuat dari mur baut dengan panjang $8 \mathrm{~cm}$ yang terpasang di bidang dial Sundial Pranata Mangsa. Dengan adanya tripod tersebut memudahkan untuk mengatur kedataran bidang dialnya.

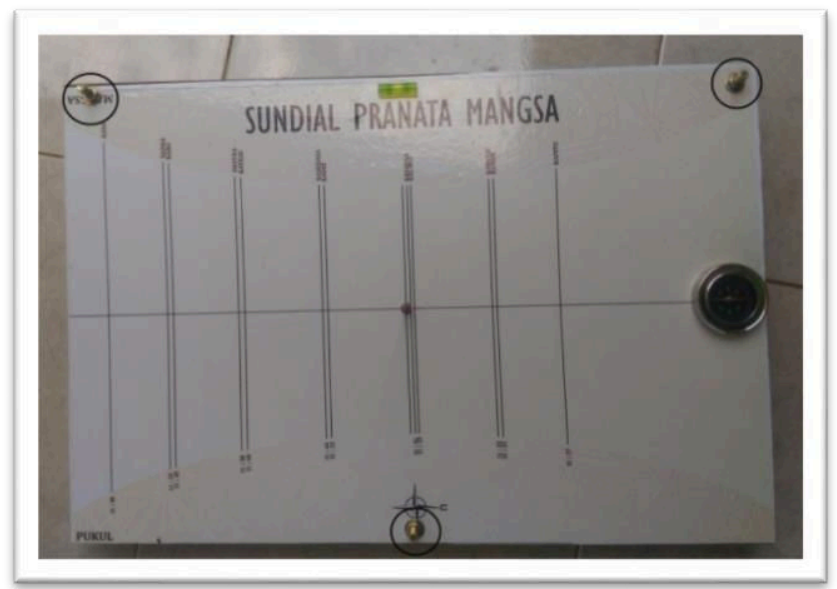

Gambar 5: Posisi Tripod. (Sumber: Penulis) 
$130 \mid$ Muhammad Himmatur Riza

\section{Bidang Dial}

Bidang dial pada Sundial Pranata Mangsa berbentuk persegi panjang dengan ukuran $60 \times 40 \mathrm{~cm}$. Dalam pembuatan bidang dial pada Sundial Pranata Mangsa ini menyesuaikan tinggi gnomon $45 \mathrm{~cm}$. Penyesuaian ini, bertujuan ketika masuk awal mangsa Kasa dan mangsa Kapitu bayangan gnomon yang jatuh pada bidang dial tepat menunjuk pada skala atau garisgaris tanggal dan bidang dial dapat menjangkau panjang bayangan.

Pada bidang dial dalam Sundial Pranata Mangsa ini, terdapat skala atau garis-garis tanggal awal mangsa-mangsa penanggalan Jawa Pranata Mangsa dan petunjuk waktu ketika matahari berkulminasi. Skala atau garis-garis tanggal ini adalah panjang bayangan yang dihasilkan gnomon ketika Matahari berkulminasi. Untuk menghitung skala atau garis-garis tanggal tersebut membutuhkan dua data, yaitu lintang tempat dan deklinasi Matahari.

Setelah mendapatkan dua data tersebut, kemudian dimasukkan ke dalam rumus mencari jarak zenith $(\mathrm{ZM}):^{20}$

$\mathrm{ZM}$ (jarak zenith) $=\left[\delta-\phi^{\mathrm{x}}\right]^{21}$

Kemudian, hasil dari jarak zenith tersebut digunakan untuk mengetahui garis-garis tanggal awal-awal mangsa dalam penanggalan Jawa Pranata Mangsa dengan mengggunakan rumus:

Tan $x=\frac{\text { depan }}{\text { Samping }}$
Depan $=$ Tan $x$. Samping

20 Slamet Hambali, Ilmu Falak 1 (Penentuan Awal Waktu Shalat dan Arah Kiblat Seluruh Dunia), (Semarang: Program Pascasarjana IAIN Walisongo Semarang, 2011), 57.

${ }^{21}$ Hasil dari rumus jarak zenith adalah harga mutlak.

Ulul Albab: Jurnal Studi dan Penelitian Hukum Islam 


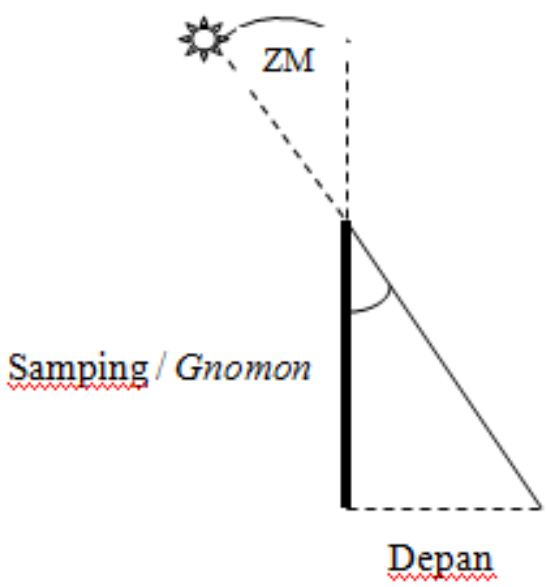

Gambar 6: Ilustrasi Matahari ketika kulminasi.

(Sumber:Penulis)

Prinsip dari sundial Pranata Mangsa ini hanya bersifat lokal, sehingga hanya dapat digunakan di satu kota saja. Penulis membuat Sundial Pranata Mangsa ini hanya diperuntukkan kota Semarang, adapun lintang tempat kota semarang adalah $-07^{\circ} 00^{\prime 22}$, dan data dekinasi Matahari penulis ambil dari buku Ephemeris Hisab Rukyat ${ }^{23}$ tahun 2018, karena penulis melakukan penelitian ini pada tahun 2018. Adapun data-data deklinasi adalah sebagai berikut:

\begin{tabular}{|l|l|c|c|}
\hline No. & Mangsa & Tanggal & $\begin{array}{c}\text { Deklinasi } \\
\text { Matahari }\end{array}$ \\
\hline 1. & Kasa & 22 Juni & $23^{\circ} 25^{\prime} 59^{\prime \prime}$ \\
\hline 2. & Karo & 2 Agustus & $17^{\circ} 46^{\prime} 21^{\prime \prime}$ \\
\hline 3. & Katelu & 25 Agustus & $10^{\circ} 46^{\prime} 31^{\prime \prime}$ \\
\hline
\end{tabular}

${ }^{22}$ Ahmad Izzuddin, Ilmu Falak Praktis, (Semarang, PT. Pustaka Rizki Putra, 2012), 267.

23 Buku Ephemeris Hisab Rukyat ini dikeluarkan oleh Direktorat Urusan Agama Islam dan Pembinaan Syariah, Direktorat Jendral Bimbingan Masyarakat Islam Kementerian Agama RI Tahun 2017. 
132 | Muhammad Himmatur Riza

\begin{tabular}{|l|l|c|c|}
\hline 4. & Kapat & 18 September & $01^{\circ} 53^{\prime} 29^{\prime \prime}$ \\
\hline 5. & Kalima & 13 Oktober & $-07^{\circ} 44^{\prime} 45^{\prime \prime}$ \\
\hline 6. & Kanem & 9 November & $-16^{\circ} 50^{\prime} 04^{\prime \prime}$ \\
\hline 7. & Kapitu & 22 Desember & $-23^{\circ} 26^{\prime} 06^{\prime \prime}$ \\
\hline 8. & Kawolu & 3 Februari & $-16^{\circ} 32^{\prime} 11^{\prime \prime}$ \\
\hline 9. & Kasanga & 1 Maret & $-07^{\circ} 36^{\prime} 34^{\prime \prime}$ \\
\hline 10. & Kasadasa & 26 Maret & $02^{\circ} 10^{\prime} 45^{\prime \prime}$ \\
\hline 11. & Dhesta & 19 April & $11^{\circ} 09^{\prime} 02^{\prime \prime}$ \\
\hline 12. & Sadha & 12 Mei & $18^{\circ} 06^{\prime} 60^{\prime \prime}$ \\
\hline
\end{tabular}

Tabel 1: Data Deklinasi Matahari pada Setiap Awal Mangsa.

(Sumber: Penulis)

Pada prinsipnya, untuk mengetahui awal mangsa dalam penanggalan Jawa Pranata Mangsa menggunakan Sundial Pranata Mangsa adalah ketika Matahari berkulminasi, jadi bayangan yang dihasilkan dari gnomon seperti contoh di atas adalah bayangan Matahari ketika berkulminasi, untuk itu langkah berikutnya adalah menentukan waktu ketika Matahari berkulminasi. Adapun data-data yang diperlukan adalah sebagai berikut:

1. Panjang bayangan

2. Deklinasi Matahari

3. Equation of Time

4. Lintang Tempat

5. Bujur Tempat

6. Bujur Daerah

Setelah data-data terkumpul, selanjutnya ke tahap perhitungan:

1. Menghitung tinggi Matahari (h).

Tan $\mathrm{h}$ = panjang tongkat : panjang bayangan

2. Menghitung sudut waktu (t)

$\operatorname{Cos} \mathrm{t}=\sin \mathrm{h}: \cos \phi^{\mathrm{x}}: \cos \delta-\tan \phi^{\mathrm{x}} \mathrm{x} \tan \delta$

3. Menghitung waktu hakiki (WH)

$\mathrm{WH}=12+\mathrm{t}: 15$ (untuk bakda zawal)

$\mathrm{WH}=12-\mathrm{t}: 15$ (untuk qobla zawal)

Ulul Albab: Jurnal Studi dan Penelitian Hukum Islam 
Sundial Horizontal dalam Penentuan .... 133

4. Menghitung wakt $\mu$ daerah (WD)

$\mathrm{WD}=\mathrm{WH}-\mathrm{e}+\left(\lambda^{\mathrm{d}}-\lambda^{\mathrm{x}}\right): 15$

Berikut tabel panjang garis-garis tanggal dan waktu matahari kulminasi pada tiap-tiap awal mangsa:

\begin{tabular}{|c|c|c|c|c|}
\hline No. & Mangsa & $\begin{array}{l}\text { Panjang } \\
\text { Bayangan }\end{array}$ & $\begin{array}{l}\text { Arah dan } \\
\text { Keadaan } \\
\text { Bayangan }\end{array}$ & Pukul \\
\hline 1. & Kasa (22 Juni) & $26,43625316 \mathrm{~cm}$ & $\begin{array}{l}\text { Selatan } \\
\text { (Berkurang) }\end{array}$ & $\begin{array}{l}\text { 11:40:21 } \\
\text { WIB }\end{array}$ \\
\hline 2. & Karo (2 Agustus) & $20,76671515 \mathrm{~cm}$ & $\begin{array}{l}\text { Selatan } \\
\text { (Berkurang) }\end{array}$ & $\begin{array}{l}\text { 11:44:42 } \\
\text { WIB }\end{array}$ \\
\hline 3. & Katelu (25 Agustus) & $14,42650404 \mathrm{~cm}$ & $\begin{array}{l}\text { Selatan } \\
\text { (Berkurang) }\end{array}$ & $\begin{array}{l}\text { 11:40:35 } \\
\text { WIB }\end{array}$ \\
\hline 4. & Kapat (18 September) & $7,03988311 \mathrm{~cm}$ & $\begin{array}{l}\text { Selatan } \\
\text { (Berkurang) }\end{array}$ & $\begin{array}{l}11: 32: 41 \\
\text { WIB }\end{array}$ \\
\hline 5. & Kalima (13 Oktober) & $0,585809218 \mathrm{~cm}$ & $\begin{array}{l}\text { Utara } \\
\text { (Bertambah) }\end{array}$ & $\begin{array}{l}11: 24: 43 \\
\text { WIB }\end{array}$ \\
\hline 6. & Kanem (9 November) & $7,800712306 \mathrm{~cm}$ & $\begin{array}{l}\text { Utara } \\
\text { (Bertambah) }\end{array}$ & $\begin{array}{l}\text { 11:22:09 } \\
\text { WIB }\end{array}$ \\
\hline 7. & Kapitu (22 Desember) & $13,27409569 \mathrm{~cm}$ & $\begin{array}{l}\text { Utara } \\
\text { (Berkurang) }\end{array}$ & $\begin{array}{l}\text { 11:36:49 } \\
\text { WIB }\end{array}$ \\
\hline 8. & Kawolu (3 Februari) & $7,559800637 \mathrm{~cm}$ & $\begin{array}{l}\text { Utara } \\
\text { (Berkurang) }\end{array}$ & $\begin{array}{l}\text { 11:52:12 } \\
\text { WIB }\end{array}$ \\
\hline 9. & Kasanga (1 Maret) & $0,4786746 \mathrm{~cm}$ & $\begin{array}{l}\text { Utara } \\
\text { (Berkurang) }\end{array}$ & $\begin{array}{l}\text { 11:50:48 } \\
\text { WIB }\end{array}$ \\
\hline 10. & Kasadasa (26 Maret) & $7,271618913 \mathrm{~cm}$ & $\begin{array}{l}\text { Selatan } \\
\text { (Bertambah) }\end{array}$ & $\begin{array}{l}\text { 11:44:09 } \\
\text { WIB }\end{array}$ \\
\hline 11. & Dhesta (19 April) & $14,7522297 \mathrm{~cm}$ & $\begin{array}{l}\text { Selatan } \\
\text { (Bertambah) }\end{array}$ & $\begin{array}{l}\text { 11:37:35 } \\
\text { WIB }\end{array}$ \\
\hline 12. & Sadha (12 Mei) & $21,095504482 \mathrm{~cm}$ & $\begin{array}{l}\text { Selatan } \\
\text { (Bertambah) }\end{array}$ & $\begin{array}{l}\text { 11:34:46 } \\
\text { WIB }\end{array}$ \\
\hline
\end{tabular}

Tabel 2: Panjang Garis-garis Tanggal dan Waktu Matahari Kulminasi pada Setiap Awal Mangsa. (Sumber: Penulis) 
$134 \mid$ Muhammad Himmatur Riza

Sundial Pranata Mangsa yang penulis buat ini, bidang dialnya hanya menampilkan skala atau garis tanggal pada awal mangsa saja. Akan tetapi Sundial Pranata Mangsa ini tetap bisa digunakan untuk mengetahui pertengahan tanggal setiap Mangsa dalam penanggalan Jawa Pranata Mangsa.

Prinsip masyarakat Jawa dalam menentukan awal mangsa yaitu menggunakan pecak kaki untuk menghitung panjang bayangan orang berdiri ketika Matahari berkulminasi. Rata-rata pecak kaki orang dewasa berkisar $25 \mathrm{~cm} .{ }^{24}$ Menurut orang jawa, satu pecak kaki adalah ujung jari telunjuk kaki sampai tumit. Dan menurut Ahli Falak, satu pecak kaki yaitu ujung jari tengah kaki sampai tumit atau satu per-tujuh (1/7) dari ketinggian seseorang. ${ }^{25}$ Jadi, ketinggian seseorang adalah tujuh kali dari pecak kaki seseorang tersebut. Hal ini dapat penulis implementasikan kepada prinsip dari Sundial Pranata Mangsa untuk mengetahui tanggal-tanggal mangsa dalam Penanggalan Jawa Pranata Mangsa, yaitu:

Tinggi gnomon $=$ Tinggi Seseorang .

Tinggi gnomon $=45 \mathrm{~cm}$

$$
\begin{aligned}
& =45: 7 \\
& =6,428571429 \mathrm{~cm} / 6,5 \mathrm{~cm} \text { (pembulatan) }
\end{aligned}
$$

Jadi satu pecak gnomon yaitu sebesar $6,5 \mathrm{~cm}$.

Untuk mengetahui tanggal-tanggal setiap mangsa dalam penanggalan Jawa Pranata Mangsa itu harus mengetahui panjang bayangan saat matahari berkulminasi terlebih dahulu. Ada 2 (dua) ketentuan untuk mengetahui hal tersebut:

1. Ketika ada bayangan yang sudah diketahui panjangnya dan keadaannya (berkurang), maka ambil lah panjang bayangan awal mangsa dari tabel 2 yang lebih besar dari pada

${ }_{24}$ N. Daljoeni, Pokok-pokok Klimatologi, (Bandung: Penerbit Alumni, 1983), 166.

${ }^{25}$ Lihat Lampiran Catatan mata pelajaran Ilmu Falak kelas VII Madrasah Tsanawiyyah Qudsiyyah Kudus.

Ulul Albab: Jurnal Studi dan Penelitian Hukum Islam 
panjang bayangan yang sudah diketahui panjangnya dan keadaannya (berkurang), kemudian panjang bayangan yang diambil dari tabel 2 dikurangi panjang bayangan yang sudah diketahui panjangnya dan keadaannya (berkurang), selanjutnya hasil pengurangan itu dikalikan umur Mangsa yang panjang bayangannya diambil dari tabel 2, lalu hasil dari perkalian tersebut dibagi 6,5 (satu pecak gnomon) dan hasilnya adalah tanggal mangsa yang dicari.

2. Ketika ada bayangan yang sudah diketahui panjangnya dan keadaannya (bertambah), maka ambil lah panjang bayangan awal mangsa dari tabel 2 yang lebih kecil dari pada panjang bayangan yang sudah diketahui panjangnya dan keadaannya (bertambah), kemudian panjang bayangan yang diambil dari tabel 2 dibuat mengurangi panjang bayangan yang sudah diketahui panjangnya dan keadaannya (bertambah), selanjutnya hasil pengurangan itu dikalikan umur Mangsa yang panjang bayangannya diambil dari tabel 2, lalu hasil dari perkalian tersebut dibagi 6,5 (satu pecak gnomon) dan hasilnya adalah tanggal mangsa yang dicari.

Untuk mengetahui aplikasi atau cara penggunaan Sundial Horizontal (Sundial Pranata Mangsa) dalam penentuan penanggalan Jawa Pranata Mangsa adalah sebagai berikut:

1. Siapkan Sundial Horizontal (Sundial Pranata Mangsa) di tempat terbuka dan permukaan yang rata untuk mengetahui rata atau tidaknya suatu permukaan dapat diukur menggunakan water pass dan mengatur tripodnya.

2. Posisikan Sundial Horizontal (Sundial Pranata Mangsa) menghadap ke utara dan selatan dengan menggunakan kompas.

3. Pasang Gnomon dengan posisi tegak lurus.

4. Amati dengan teliti bayang-bayang gnomon pada waktu yang tepat ketika Matahari berkulminasi atas pada tanggaltanggal tertentu. Maksud dari waktu yang tepat ini adalah waktu yang sesuai dengan keadaan yang semestinya. Untuk 
136 Muhammad Himmatur Riza

mendapatkan waktu yang tepat dapat ditempuh dengan cara :26

a. Menyesuaikan suara "tiit" terakhir RRI setiap menjelang berita.

b. Menyesuaikan dengan jam di Global Positioning System (GPS) yang sedang connect dengan satelit.

c. Menyesuaikan dengan Greenwich Mean Time (GMT) dalam internet melalui : http://wwp.greenwichmeantime.co.uk/ atau menyesuaikan langsung WIB, WITA dan WIT di internet melalui:

http://wwp.greenwichmeantime.co.uk/timezone/asia/indo nesia/

d. Menyesuaikan dengan aplikasi-aplikasi Android penunjuk waktu yang terhubung online dengan internet, seperti GPS Time, Smart Time Sync, ClockSync, UTC Time, Atomic Clock dan sebagainya.

e. Menyesuaikan dengan Jam BMKG dalam internet melalui : http://jam.bmkg.go.id

5. Lihatlah baying-bayang tersebut menyentuh pada skala atau garis tanggal yang terdapat pada bidang dial.

\section{Keakuratan Sundial Horizontal untuk Menentukan Penanggalan Jawa Pranata Mangsa}

Peneliti melakukan praktek sebanyak 3 (tiga) kali yang bertempat di halaman Pesantren Life Skill Daarun Najaah Wonosari Ngaliyan Semarang untuk membuktikan keakuratan Sundial Pranata Mangsa untuk menentukan awal setiap mangsa dalam Penanggalan Jawa Pranata Mangsa.

${ }^{26}$ Slamet Hambali, Menguji Tingkat Keakuratan : Hasil Pengukuran Arah Kiblat Menggunakan Istiwaaini Karya Slamet Hambali, (Semarang: IAIN Walisongo, 2014), 9.

Ulul Albab: Jurnal Studi dan Penelitian Hukum Islam 
1. Praktek pertama,|dilakukan pada tanggal 19 April 2018 untuk menentukan awal mangsa Dhesta pada pukul 11:37:35 WIB atau saat Matahari kulminasi atas.

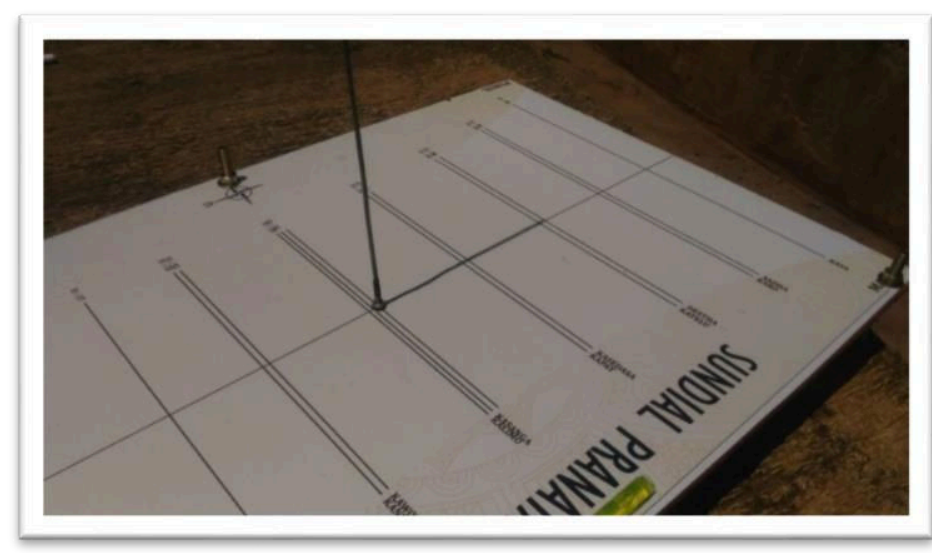

Gambar 7: Hasil Praktek pertama (Sumber: Penulis)

2. Praktek kedua, dilakukan pada tanggal 12 Mei 2018 untuk menentukan awal mangsa Sadha pada pukul 11:34:46 WIB atau saat Matahari kulminasi atas.

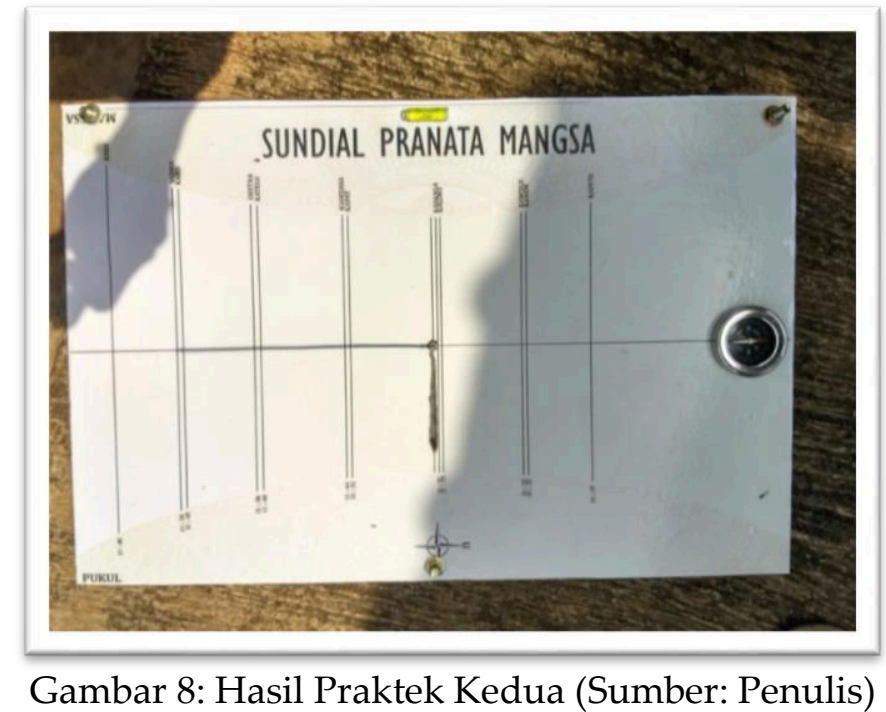

Vol. 2, No. 1, Oktober 2018, 119-142 
138 Muhammad Himmatur Riza

3. Praktek ketiga, dilakukan pada tanggal 22 Juni 2018 untuk menentukan awal mangsa Kasa pada pukul 11:40:21 WIB atau saat Matahari kulminasi atas.

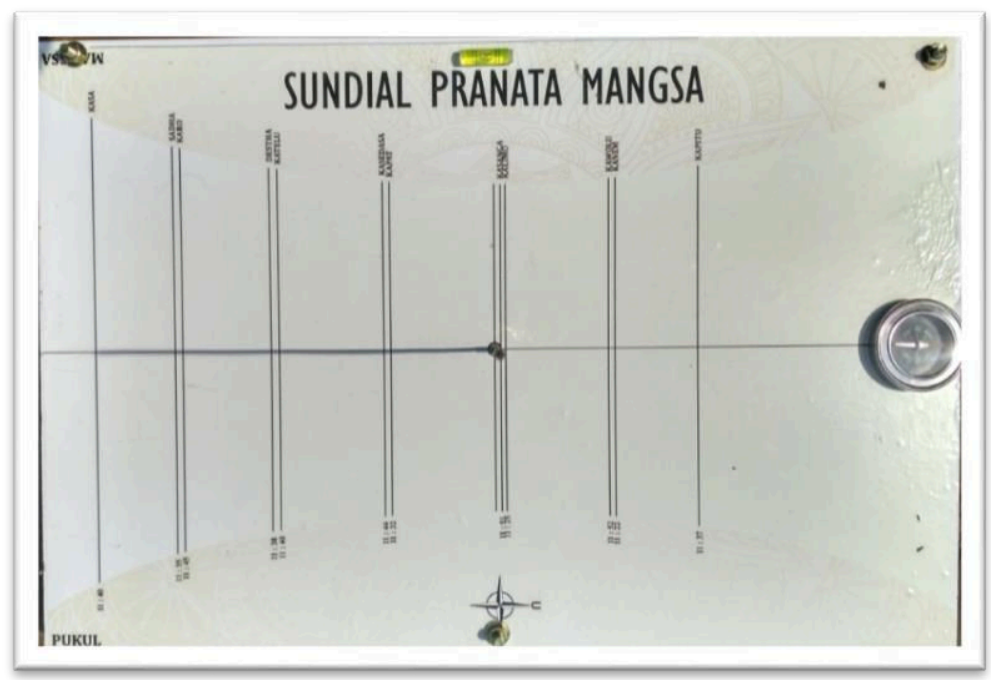

Gambar 9: Hasil Praktek Ketiga (Sumber: Penulis)

Berdasarkan hasil praktek di atas, Sundial Pranata Mangsa ini dapat digunakan untuk penentuan awal Mangsa pada penanggalan Jawa Pranata Mangsa yang praktis, mudah, dan akurat, karena ujung bayangan gnomon ketika Matahari kulminasi tepat menyentuh skala atau garis tanggal awal Mangsa. Namun hal ini sangat kemungkinan terjadi human error sehingga ujung bayangan gnomon ketika Matahari kulminasi tidak tepat menyentuh skala atau garis tanggal setiap Mangsa.

Terdapat beberapa kelebihan dan kekurangan dalam penggunaan Sundial Pranata Mangsa untuk menentukan awal Mangsa pada penanggalan Jawa Pranata Mangsa. Beberapa kelebihan di antaranya yaitu :

Ulul Albab: Jurnal Studi dan Penelitian Hukum Islam 
1. Sundial Pranata Mangsa ini dapat dipraktekkan dengan biaya murah dan terjangkau. Karena untuk membuatnya tidak mengeluarkan biaya yang mahal.

2. Sundial Pranata Mangsa lebih akurat dan lebih praktis dibanding menggunakan pecak kaki untuk penentuan penanggalan Jawa Pranata Mangsa.

3. Dengan hanya menggunakan bayangan Matahari saat kulminasi, dapat menentukan tanggal Pranata Mangsa yang bisa dikonversi ke tanggal Masehi.

4. Selain digunakan untuk menentukan penanggalan Jawa Praata Mangsa, Sundial Pranata Mansa ini juga dapat digunakan sebagai alat bantu untuk penentuan arah kiblat.

Di samping memiliki beberapa kelebihan, Sundial Pranata Mansa juga mempunyai beberapa kekurangan, diantaranya :

1. Sundial Pranata Mangsa bersifat lokal. Artinya hanya dapat digunakan untuk satu kota saja.

2. Sundial Pranata Mangsa ini hanya bisa digunakan di tempat yang mendapatkan hamparan sinar Matahari. Begitupun juga ketika mendung atau pun hujan, alat ini tidak dapat digunakan.

3. Bidang dial Sundial Pranata Mangsa ini tidak mempunyai skala atau garis tanggal untuk pertengahan tanggal selain tanggal awal mangsa.

4. Alat ini tidak dibuat permanen. Karena untuk memudahkan mengatur posisi ketika alat ini digunakan di tempat yang lain (harus tetap dalam kota).

\section{Kesimpulan}

Berdasarkan pembahasan dan analisis dari beberapa bab terdahulu, maka selanjutnya penulis akan menyimpulkan sebagai jawaban atas beberapa pokok permasalahan sebagai berikut: 
$140 \mid$ Muhammad Himmatur Riza

1. Dalam sundial ini penulis menggunakan rumus matematis yang bisa dipertanggungjawabkan untuk mengetahui panjang bayangan dan waktu Matahari saat kulminasi yang selanjutnya dibuat skala pada bidang dial-nya. Selain itu ujung gnomon yang sangat lancip juga mempengaruhi hasil pengamatan sehingga bayangan saat Matahari kulminasi yang dihasilkan dari gnomon dapat terfokus ketika menyentuh skala atau garis tanggal awal mangsa. Adapun Aplikasi atau cara penggunaan Sundial Horizontal dalam penentuan penanggalan Jawa Pranata Mangsa adalah menempatkan Sundial Horizontal di tempat yang rata dan posisikan Sundial Horizontal menghadap ke utara dan selatan dengan menggunakan kompas, selanjutnya amati dengan teliti bayang-bayang gnomon pada waktu yang tepat ketika Matahari berkulminasi pada tanggal-tanggal tertentu, terakhir lihatlah bayang-bayang dari gnomon tersebut menyentuh pada skala atau garis tanggal yang terdapat pada bidang dial.

2. Penentuan penanggalan Jawa Pranata Mangsa menggunakan Sundial Horizontal (Sundial Pranata Mangsa) lebih akurat dibandingkan dengan menggunakan pecak kaki seseorang, ini murni dari bagaimana pengguna melaksanakan praktek lapangan secara langsung dalam penentuan penanggalan Jawa Pranata Mangsa, Dari hasil praktek tersebut dapat dikatakan bahwa Sundial Horizontal (Sundial Pranata Mangsa) layak digunakan untuk penentuan penanggalan Jawa Pranata Mangsa yang akurat, praktis dan murah.

\section{Daftar Pustaka}

Azwar, Syaifuddin. 2004. Cet. Ke-5. Metode Penelitian. Yogyakarta: Pustaka Pelajar.

Direktorat Urusan Agama Islam dan Pembinaan Syariah. 2017. Buku Ephemeris Hisab Rukyat. Jakarta: Direktorat Jendral Bimbingan Masyarakat Islam Kementerian Agama RI.

Ulul Albab: Jurnal Studi dan Penelitian Hukum Islam 
Sundial Horizontal dalam Penentuan .... 141

Daljoeni, N. 1983. Pфnanggalan Pertanian Jawa Pranata Mangsa. Yogyakarta: Proyek Javanologi.

------------. 1983. Pokok-pokok Klimatologi. Bandung: Penerbit Alumni.

Darsono, Ruswa. 2010. Penanggalan Islam: Tinjauan Sistem, Fiqih dan Hisab Penanggalan. Yogyakarta:Labda Press.

Fakultas Syari'ah IAIN Walisongo. 2010. Pedoman Penulisan Sekripsi. Semarang: Fakultas Syari'ah IAIN Walisongo.

Hambali, Slamet. 2011. Ilmu Falak 1 (Penentuan Awal Waktu Shalat dan Arah Kiblat Seluruh Dunia). Semarang: Program Pascasarjana IAIN Walisongo Semarang.

--------------. 2014. Menguji Tingkat Keakuratan: Hasil Pengukuran Arah Kiblat Menggunakan Istiwaaini Karya Slamet Hambali. Semarang: IAIN Walisongo.

Izzuddin, Ahmad. 2012. Ilmu Falak Praktis. Semarang: PT. Pustaka Rizki Putra.

Kamal, Rini Fidiyani dan Ubaidillah. Cara berhukum Orang Banyumas dalam Pengelolaan Lahan Pertanian (Studi Berdasarkan Antropologi Hukum). Semarang: Fakultas Hukum Universitas Negeri Semarang.

Khazin, Muhyiddin. Ilmu Falak dalam Teori dan Praktik. Yogyakarta: Buana Pustaka.

Pustaka.

Hasan, M. Iqbal. 2002. Pokok-Pokok Metodologi Penelitian dan Aplikasinya. Bogor: Ghalia Indonesia.

Ratna, Nyoman Kutha. 2010. Metodologi Penelitian. Yogyakarta: Pustaka Pelajar.

Rohr, Rene. R. J. 1996. Sundial, History, Theory and Pactice. New York: Dover Publications, INC.

Saksono, Tono. 2007. Mengkompromikan Rukyat $\mathcal{E}$ Hisab. Jakarta: Amythas Publicita.

Sindhunata. 2011. Seri Lawasan Pranata Mangsa. Jakarta: Kepustakaan Populer Gramedia. 
142 Muhammad Himmatur Riza

Wisnubroto, Sukardi. 1999. Pengenalan waktu Tradisional Pranata Mangsa dan Wariga menurut Jabaran Meteorologi Manfaatnya dalam Pertanian dan Sosial. Yogyakarta: Mitra Gama Widya.

http://artrevolution.wordpress.com/category/sejarah-jam/.

Diakses pada tanggal 23 Juni 2018 pukul 20:35 WIB.

http://id.m.wikipedia.org/wiki/waterpass. diakses pada hari Rabu, 24 Juni 2018 pukul 19.16 WIB.

http://www.cybersoe.com/index.php/soe-pedia/fisika?start=10.

Diakses pada tanggal 23 Juni 2018 pukul 20:05 WIB. 